\title{
Estimation of short-lived climate forced sulfur dioxide in Tehran, Iran, using machine learning analysis
}

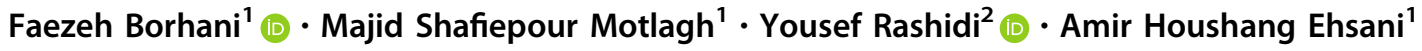

Accepted: 24 December 2021 / Published online: 8 January 2022

(C) The Author(s), under exclusive licence to Springer-Verlag GmbH Germany, part of Springer Nature 2022

\begin{abstract}
This paper presents a time-series analysis of $\mathrm{SO}_{2}$ air concentration and the effects of particulates (either $\mathrm{PM}_{2.5}$ and $\mathrm{PM}_{10}$ ) concentrations and meteorological conditions (relative humidity and wind speed) on $\mathrm{SO}_{2}$ trend in Tehran for the period from 2011 to 2020. The source data were obtained from 21 monitoring stations of Air Quality Control Company and meteorological stations in Tehran. To predict the status of future concentration of $\mathrm{SO}_{2}, \mathrm{PM}_{2.5}$ and $\mathrm{PM}_{10}$, a Box-Jenkins ARIMA approach was used to model the monthly time series. Considering the whole period of ten years, a somewhat downward trend was noted for $\mathrm{SO}_{2}$ air concentration, even though a slight rising trend was observed in 2020 year. Monthly sulfur dioxide concentrations showed the lowest value in June and the highest value in January. Seasonal concentrations were lowest in spring and highest in winter. Then, in the ArcGIS software, the IDW method was used to obtain air pollution zoning maps. As a result, the highest average concentration of $\mathrm{SO}_{2}$ occurred in the north and southwest of Tehran. In the last step, Relations between the $\mathrm{SO}_{2}$ concentration and particulate matters and relative humidity and wind speed were calculated statistically using the daily average data. We finally concluded that the combined effect of particulate matters and relative humidity with the increasing role of Sulfur dioxide overcomes the decreasing role of wind speed. This study can contribute to a better understanding of the $\mathrm{SO}_{2}$ air pollution in Tehran affected by meteorological conditions and the rapid urbanization and industrialization, followed by the possible combustion of fuel oil in power plants and health problems.
\end{abstract}

Keywords Sulfur dioxide $\cdot$ Short-lived climate pollutants $\cdot$ Meteorological parameters $\cdot$ Air pollution $\cdot$ Machine learning $\cdot$ ARIMA forecasting

\section{Introduction}

Atmospheric Sulfur dioxide $\left(\mathrm{SO}_{2}\right)$, emitting from anthropogenic and natural sources, is one of the most important air pollutants leading to climate change, environmental

Faezeh Borhani

fborhani78@ut.ac.ir

Majid Shafiepour Motlagh

shafiepour@ut.ac.ir

Yousef Rashidi

y_rashidi@sbu.ac.ir

Amir Houshang Ehsani

ehsani@ut.ac.ir

1 School of Environment, College of Engineering, University of Tehran, P.O. Box, 14155-6135 Tehran, Iran

2 Environmental Sciences Research Institute, Shahid Beheshti University, Tehran, Iran problems and health risks (Braga et al. 2006; Gonçalves et al. 2005; Krotkov et al. 2016; Mallik and Lal 2014; Pereira et al. 2009; Hoveidi et al. 2017; Borhani and Noorpoor 2020). Sulfur dioxide can cause a number of harmful effects on the lungs, (i.e., Wheezing, breathing problems, chest tightness) (EPA 2008; Yun et al. 2015). While $\mathrm{PM}_{2.5}$ (Particulate Matter with $2.5 \mu \mathrm{m}$ or less in aerodynamic diameter) is deposited on the surface of the deeper parts of the lungs and $\mathrm{PM}_{10}$ (Particulate Matter with $10 \mu \mathrm{m}$ or less in aerodynamic diameter) on the surface of the larger airways in the upper part of the lungs. Particulate matter deposited on the lung surface can lead to tissue 
damage and lung inflammation (Wei and Tang 2018; Losacco and Perillo 2018; Happo 2009). $\mathrm{SO}_{2}$ is one of the five main pollutants that together account for more than $90 \%$ of air pollution in the world (Sharma 2001). Sulfur oxides in combination with particulate matter and moisture (e.g. humidity) in ambient air produce the most harmful effects associated with atmospheric air pollution (Dutkiewicz et al. 2000; Moldan et al. 2001). Numerous studies to show that exposure to $\mathrm{SO}_{2}, \mathrm{PM}_{2.5}$, and $\mathrm{PM}_{10}$ Periodontitis increases the risk of respiratory diseases in adults, during the COVID-19 pandemic (Borhani et al. 2021a; Zoran et al. 2020; Zou et al. 2020; Wu et al. 2020). Sulfur dioxide $\left(\mathrm{SO}_{2}\right)$ is one of the Short-lived climate forcers (SLCF). Short-lived climate forcers (SLCF) are also known to as short-lived climate pollutants (SLCP) (Randall et al. 2008; Retama et al. 2015; Stohl et al. 2015; Kindbom et al. 2019). $\mathrm{SO}_{2}$ remains in the air for an average of 2 to 4 days (Turalıoglu et al. 2005). $\mathrm{SO}_{2}, \mathrm{PM}_{2.5}, \mathrm{PM}_{10}$ are precursors of aerosols (Wang et al. 2015).

Although the relationships between meteorological conditions and $\mathrm{SO}_{2}$ air pollution have been investigated, such as, Kalkstein and Corrigan (1986) examined a synoptic climatological approach to assessing the effects of climate on sulfur dioxide concentrations. Elminir (2005) mentioned dependence of air pollutants on meteorological conditions over Cairo in Egypt. And Several works have been carried out to study $\mathrm{SO}_{2}$ air pollution in Iran. Such as, Geravandi et al. (2015) investigated the effects of nitrogen dioxide $\left(\mathrm{NO}_{2}\right)$ and sulfur dioxide $\left(\mathrm{SO}_{2}\right)$ exposure related to health and increased premature deaths in Ahvaz, the capital of Khuzestan province, Iran. The results showed that about $5.6 \%$ of respiratory mortality and chronic obstructive pulmonary disease cases occurred when nitrogen dioxide $\left(\mathrm{NO}_{2}\right)$ and sulfur dioxide $\left(\mathrm{SO}_{2}\right)$ concentrations were above $20 \mu \mathrm{g} \mathrm{m}^{-3}$. Masoudi et al. (2018) studied the effects of meteorological factors on the prediction of $\mathrm{SO}_{2}$ and the relationships between air pollutants and some meteorological parameters in Tehran from 2009 to 2010. Shen et al. (2020) proposed a machine learning-based extreme learning model to predict the concentration and ratio of air pollutants $\left(\mathrm{O}_{3}, \mathrm{CO}, \mathrm{NO}_{2}, \mathrm{SO}_{2}, \mathrm{PM}_{2.5}, \mathrm{PM}_{10}\right)$ in Seoul, the capital of South Korea. Bhatti et al. (2021) analyzed the relationship between pollutants $\left(\mathrm{CO}, \mathrm{NO}, \mathrm{O}_{3}, \mathrm{SO}_{2}\right)$ using a time series model to predict subsequent concentrations. Naseem et al. (2018) used an autoregressive integrated moving average (ARIMA) model to predict air quality time series data and then evaluated its application in air quality management decision making.

We still have very little information on the dependence of sulfur dioxide emissions on the geographic and meteorological conditions of the city and the emission rate from stationary and mobile sources. This study aimed to examine the relationship between $\mathrm{SO}_{2}, \mathrm{PM}_{10}$ and $\mathrm{PM}_{2.5}$ concentrations in ambient air and meteorological conditions in Tehran using the auto-regressive integrated moving average (ARIMA) method and statistical tools of analysis. we tried to make a time series model to forecast the environmental air quality time series data. Therefore, first, exhibits monthly, seasonal and annual variations of concentration of sulfur dioxide and particulates (either $\mathrm{PM}_{10}$ and $\mathrm{PM}_{2.5}$ ) in the Tehran air over ten years (2011-2020). In the second step, the effect of particulate matter (i.e., $\mathrm{PM}_{10}$ and $\mathrm{PM}_{2.5}$ ), wind speed, WS, and relative humidity, (RH in $\%)$ ) on variations of sulfur dioxide concentration based on Pearson correlations between sulfur dioxide and its precursors were also analyzed. In the third step, the concentration distribution of the air pollutants in 21 air quality monitoring stations of the regions were zoned based on the measurements with the ArcGIS software using Inverse distance weighting (IDW) interpolation method. Finally, we use a time series model for the prediction of sulfur dioxide and particulate matter concentrations and wind speed and relative humidity. Figure 1 shows a flowchart of the steps followed during the research.

\section{Materials and methods}

\subsection{The study area}

Tehran, the largest metropolitan center in Iran, is located at about $35^{\circ} 41^{\prime} 21^{\prime \prime} \mathrm{N}$ and $51^{\circ} 23^{\prime} 20^{\prime \prime} \mathrm{E}$ (see Fig. 2). The total area covered by the city is about $751 \mathrm{~km}^{2}$. The average annual precipitation amounts to $245.8 \mathrm{~mm}$. The highest temperature in Tehran is $43{ }^{\circ} \mathrm{C}$ and the lowest temperature is $-15^{\circ} \mathrm{C}$. The average relative humidity is about $40 \%$. The prevailing wind is West Tehran $\left(270^{\circ}\right)$ and its average speed is $5.5 \mathrm{~m} / \mathrm{s}$. Tehran city has a population of 8.7 million approximately. There are a number of reasons for air pollution in Tehran, some of which are in the industrial sector, the transportation sector, and the geographical location of the city, with the large Alborz Mountains in the north of the city contributing to pollution levels. Tehran is thus one of the most polluted cities in Iran, which is why an analysis of air quality in this city must be conducted.

\subsection{Field measurement}

In Tehran city, the automatic measurement of air quality is performed by 21 measuring stations of Air Quality Control Company (AQCC 2020). Figure 2 shows the location of the air pollution monitoring stations. The paper presents the analysis of $\mathrm{SO}_{2}, \mathrm{PM}_{10}$ and $\mathrm{PM}_{2.5}$ concentrations measurements collected at 21 stations which provided the information for a database covering a period of ten years: 


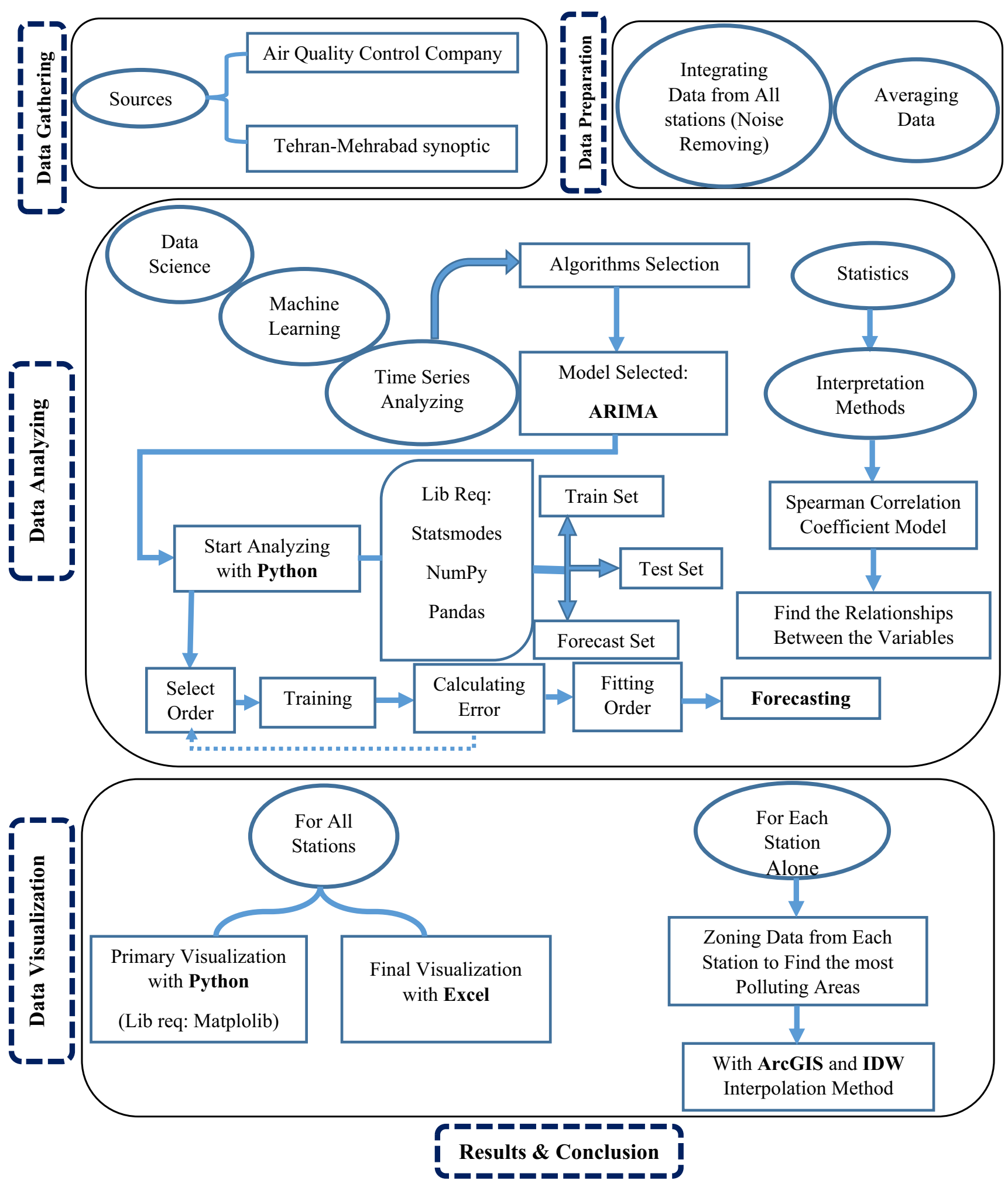

Fig. 1 Flow chart of research methodology

2011-2020 (Table 1). all air quality monitoring stations with $>75 \%$ of the hourly data over the year were used for further calculations, as less than $0.1 \%$ of the $\mathrm{SO}_{2}$ data for each station was removed from the data set and subsequent calculations. The incoming information was converted into standard concentrations based on the Clean Discussion Guidelines issued by the US Natural Security Organization 


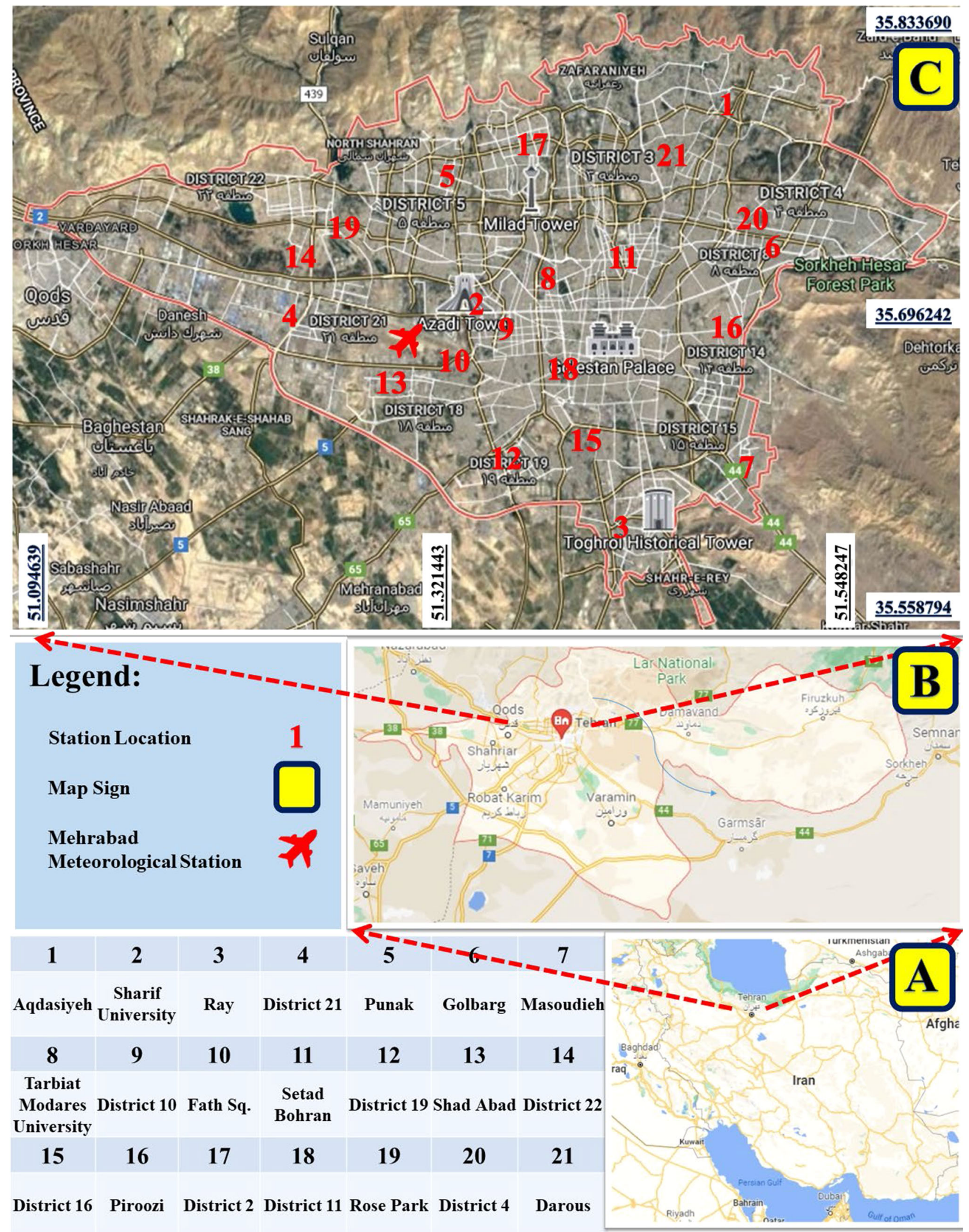

Fig. 2 The locations of the air quality monitoring stations and the Mehrabad synoptic station in Tehran. a Iran, b Tehran Province, $\mathbf{c}$ Tehran City 
Table 1 Annual average of $\mathrm{SO}_{2}, \mathrm{PM}_{2.5}, \mathrm{PM}_{10}$ and $\mathrm{RH}$ and WS recorded from 2011 to 2020 in Tehran

\begin{tabular}{|c|c|c|c|c|c|c|c|c|c|c|c|c|c|}
\hline \multirow[t]{3}{*}{ Year } & \multirow[t]{3}{*}{ Parameters } & \multicolumn{12}{|l|}{ Dataset } \\
\hline & & \multicolumn{3}{|l|}{ Winter } & \multicolumn{3}{|l|}{ Spring } & \multicolumn{3}{|c|}{ Summer } & \multicolumn{3}{|l|}{ Autumn } \\
\hline & & Jan & Feb & Mar & Apr & May & Jun & Jul & Aug & Sep & Oct & Nov & Dec \\
\hline \multirow[t]{5}{*}{2011} & $\mathrm{SO}_{2}(\mathrm{ppb})$ & 26.50 & 18.73 & 19.00 & 18.93 & 18.47 & 18.64 & 17.57 & 18.50 & 25.40 & 21.25 & 20.69 & 22.94 \\
\hline & $\mathrm{PM}_{2.5}\left(\mu \mathrm{g} \mathrm{m}^{-3}\right)$ & 38.67 & 27.67 & 32.33 & 44.50 & 41.50 & 37.75 & 35.75 & 42.25 & 45.25 & 39.00 & 34.50 & 43.50 \\
\hline & $\mathrm{PM}_{10}\left(\mu \mathrm{g} \mathrm{m}^{-3}\right)$ & 96.36 & 62.43 & 60.07 & 103.71 & 95.21 & 111.61 & 96.85 & 106.85 & 93.71 & 93.13 & 80.27 & 105.33 \\
\hline & RH (\%) & 58.95 & 48.36 & 45.58 & 26.74 & 27.62 & 19.17 & 17.10 & 26.87 & 23.90 & 45.00 & 66.28 & 52.88 \\
\hline & WS (Knot) & 4.63 & 7.41 & 5.81 & 7.71 & 8.60 & 7.90 & 6.58 & 6.50 & 5.34 & 6.22 & 5.00 & 3.96 \\
\hline \multirow[t]{5}{*}{2012} & $\mathrm{SO}_{2}(\mathrm{ppb})$ & 29.91 & 26.00 & 22.09 & 17.38 & 16.71 & 18.57 & 21.61 & 18.93 & 19.23 & 19.77 & 18.23 & 21.77 \\
\hline & $\mathrm{PM}_{2.5}\left(\mu \mathrm{g} \mathrm{m}^{-3}\right)$ & 34.33 & 33.33 & 34.00 & 33.00 & 41.56 & 32.90 & 38.64 & 31.15 & 32.36 & 36.50 & 35.14 & 44.50 \\
\hline & $\mathrm{PM}_{10}\left(\mu \mathrm{g} \mathrm{m}^{-3}\right)$ & 75.50 & 73.30 & 63.50 & 72.08 & 108.00 & 79.23 & 84.31 & 77.87 & 83.60 & 80.00 & 71.06 & 90.94 \\
\hline & $\mathrm{RH}(\%)$ & 48.66 & 52.74 & 32.14 & 38.75 & 23.79 & 21.67 & 23.06 & 18.41 & 24.43 & 33.39 & 52.34 & 64.96 \\
\hline & WS (Knot) & 5.88 & 6.08 & 8.69 & 6.54 & 8.59 & 6.31 & 6.15 & 5.48 & 5.51 & 5.23 & 4.22 & 4.27 \\
\hline \multirow[t]{5}{*}{2013} & $\mathrm{SO}_{2}(\mathrm{ppb})$ & 24.60 & 22.00 & 17.27 & 18.00 & 19.20 & 20.18 & 15.27 & 16.75 & 15.67 & 16.00 & 16.64 & 17.73 \\
\hline & $\mathrm{PM}_{2.5}\left(\mu \mathrm{g} \mathrm{m}^{-3}\right)$ & 43.60 & 35.71 & 31.40 & 24.92 & 23.54 & 37.46 & 37.83 & 33.27 & 33.70 & 36.91 & 33.67 & 35.46 \\
\hline & $\mathrm{PM}_{10}\left(\mu \mathrm{g} \mathrm{m}^{-3}\right)$ & 100.18 & 80.41 & 76.53 & 67.19 & 68.25 & 106.87 & 112.20 & 97.57 & 90.57 & 101.60 & 84.56 & 79.73 \\
\hline & $\mathrm{RH}(\%)$ & 45.63 & 44.34 & 35.15 & 30.54 & 28.37 & 20.77 & 21.93 & 24.08 & 18.67 & 31.50 & 53.52 & 50.79 \\
\hline & WS (Knot) & 5.85 & 6.07 & 7.49 & 7.11 & 8.57 & 8.00 & 6.78 & 6.32 & 6.38 & 5.57 & 4.27 & 5.61 \\
\hline \multirow[t]{5}{*}{2014} & $\mathrm{SO}_{2}(\mathrm{ppb})$ & 19.89 & 19.89 & 15.22 & 19.50 & 21.00 & 14.12 & 11.69 & 14.91 & 16.91 & 15.78 & 17.50 & 18.60 \\
\hline & $\mathrm{PM}_{2.5}\left(\mu \mathrm{g} \mathrm{m}^{-3}\right)$ & 38.62 & 35.85 & 24.85 & 21.90 & 22.80 & 34.33 & 36.00 & 29.00 & 34.45 & 32.09 & 29.50 & 37.91 \\
\hline & $\mathrm{PM}_{10}\left(\mu \mathrm{g} \mathrm{m}^{-3}\right)$ & 78.40 & 85.57 & 64.28 & 57.21 & 64.13 & 94.46 & 95.21 & 86.17 & 94.36 & 84.00 & 69.60 & 86.33 \\
\hline & $\mathrm{RH}(\%)$ & 54.36 & 44.68 & 36.58 & 32.38 & 24.73 & 18.48 & 19.34 & 16.08 & 19.04 & 37.65 & 49.23 & 53.61 \\
\hline & WS (Knot) & 5.26 & 5.07 & 8.18 & 7.44 & 7.72 & 8.00 & 6.78 & 6.16 & 6.21 & 6.57 & 4.58 & 4.39 \\
\hline \multirow[t]{5}{*}{2015} & $\mathrm{SO}_{2}(\mathrm{ppb})$ & 21.29 & 18.00 & 15.94 & 13.00 & 13.22 & 14.05 & 14.88 & 17.37 & 16.23 & 17.71 & 14.56 & 13.88 \\
\hline & $\mathrm{PM}_{2.5}\left(\mu \mathrm{g} \mathrm{m}^{-3}\right)$ & 33.07 & 29.75 & 25.00 & 22.69 & 26.25 & 38.06 & 27.82 & 26.91 & 25.00 & 25.75 & 37.00 & 41.23 \\
\hline & $\mathrm{PM}_{10}\left(\mu \mathrm{g} \mathrm{m}^{-3}\right)$ & 79.53 & 76.23 & 65.28 & 68.61 & 77.39 & 107.56 & 89.47 & 101.33 & 89.06 & 111.00 & 82.40 & 84.14 \\
\hline & $\mathrm{RH}(\%)$ & 42.41 & 47.34 & 41.90 & 23.20 & 20.51 & 16.02 & 18.96 & 21.18 & 26.18 & 38.57 & 50.11 & 61.62 \\
\hline & WS (Knot) & 5.07 & 6.00 & 6.89 & 29 & 7.61 & 6.93 & 5.98 & 5.65 & 5.42 & 5.78 & 4.89 & 4.51 \\
\hline \multirow[t]{5}{*}{2016} & $\mathrm{SO}_{2}(\mathrm{ppb})$ & 13.87 & 15.44 & 11.07 & 8.36 & 9.00 & 8.27 & 13.91 & 9.54 & 10.00 & 10.87 & 12.38 & 11.93 \\
\hline & $\mathrm{PM}_{2.5}\left(\mu \mathrm{g} \mathrm{m}^{-3}\right)$ & 27.71 & 32.08 & 23.38 & 22.43 & 25.50 & 30.14 & 35.20 & 35.21 & 31.33 & 29.50 & 42.00 & 42.00 \\
\hline & $\mathrm{PM}_{10}\left(\mu \mathrm{g} \mathrm{m}^{-3}\right)$ & 72.46 & 87.53 & 64.36 & 59.13 & 68.27 & 95.78 & 102.53 & 92.43 & 110.36 & 94.93 & 101.43 & 83.50 \\
\hline & RH (\%) & 46.98 & 37.46 & 35.89 & 36.48 & 26.39 & 19.23 & 22.31 & 18.00 & 21.43 & 28.15 & 41.48 & 52.64 \\
\hline & WS (Knot) & 5.76 & 6.04 & 8.75 & 7.57 & 8.47 & 8.14 & 7.03 & 5.19 & 6.66 & 4.71 & 4.61 & 5.14 \\
\hline \multirow[t]{5}{*}{2017} & $\mathrm{SO}_{2}(\mathrm{ppb})$ & 12.46 & 9.50 & 7.00 & 6.11 & 5.62 & 5.59 & 5.94 & 6.40 & 8.75 & 7.76 & 6.75 & 9.50 \\
\hline & $\mathrm{PM}_{2.5}\left(\mu \mathrm{g} \mathrm{m}^{-3}\right)$ & 42.69 & 31.37 & 23.44 & 22.87 & 28.81 & 27.87 & 28.87 & 29.56 & 30.69 & 34.00 & 37.31 & 52.81 \\
\hline & $\mathrm{PM}_{10}\left(\mu \mathrm{g} \mathrm{m}^{-3}\right)$ & 84.71 & 69.73 & 56.53 & 69.87 & 77.87 & 78.00 & 82.50 & 90.07 & 95.78 & 97.20 & 102.27 & 105.73 \\
\hline & $\mathrm{RH}(\%)$ & 49.88 & 47.25 & 46.32 & 37.73 & 24.26 & 16.87 & 18.65 & 19.12 & 20.41 & 27.98 & 32.39 & 40.00 \\
\hline & WS (Knot) & 5.21 & 5.87 & 6.91 & 6.81 & 7.21 & 7.63 & 5.70 & 5.62 & 5.26 & 5.32 & 5.43 & 4.31 \\
\hline \multirow[t]{5}{*}{2018} & $\mathrm{SO}_{2}(\mathrm{ppb})$ & 8.50 & 7.07 & 6.13 & 4.88 & 3.00 & 3.87 & 4.86 & 4.80 & 5.07 & 5.26 & 5.40 & 6.27 \\
\hline & $\mathrm{PM}_{2.5}\left(\mu \mathrm{g} \mathrm{m}^{-3}\right)$ & 40.33 & 43.47 & 30.60 & 25.06 & 25.00 & 26.14 & 32.29 & 25.86 & 25.07 & 24.57 & 29.93 & 33.80 \\
\hline & $\mathrm{PM}_{10}\left(\mu \mathrm{g} \mathrm{m}^{-3}\right)$ & 81.07 & 93.21 & 85.57 & 58.47 & 71.20 & 70.40 & 85.93 & 89.81 & 84.06 & 68.31 & 62.63 & 79.56 \\
\hline & $\mathrm{RH}(\%)$ & 47.00 & 55.95 & 27.15 & 37.08 & 37.46 & 22.26 & 14.09 & 20.00 & 21.17 & 40.36 & 59.14 & 51.50 \\
\hline & WS (Knot) & 5.34 & 5.15 & 8.38 & 6.25 & 7.18 & 6.30 & 5.65 & 6.00 & 5.58 & 5.69 & 4.29 & 4.71 \\
\hline \multirow[t]{5}{*}{2019} & $\mathrm{SO}_{2}(\mathrm{ppb})$ & 6.07 & 5.64 & 5.07 & 3.47 & 3.78 & 4.33 & 4.78 & 4.88 & 5.18 & 5.23 & 6.47 & 7.18 \\
\hline & $\mathrm{PM}_{2.5}\left(\mu \mathrm{g} \mathrm{m}^{-3}\right)$ & 33.43 & 27.36 & 19.00 & 17.00 & 22.53 & 27.07 & 29.67 & 27.50 & 26.81 & 27.06 & 45.69 & 47.9 \\
\hline & $\mathrm{PM}_{10}\left(\mu \mathrm{g} \mathrm{m}^{-3}\right)$ & 85.81 & 59.75 & 46.25 & 46.50 & 64.44 & 72.81 & 95.25 & 85.37 & 91.62 & 75.50 & 85.19 & 88.50 \\
\hline & $\mathrm{RH}(\%)$ & 51.86 & 44.44 & 43.09 & 34.07 & 25.34 & 18.13 & 18.42 & 20.52 & 24.53 & 40.02 & 57.45 & 56.81 \\
\hline & WS (Knot) & 5.81 & 6.35 & 7.11 & 7.12 & 7.96 & 5.84 & 7.24 & 6.12 & 6.20 & 5.03 & 4.36 & 4.42 \\
\hline
\end{tabular}


Table 1 (continued)

\begin{tabular}{|c|c|c|c|c|c|c|c|c|c|c|c|c|c|}
\hline \multirow[t]{3}{*}{ Year } & \multirow[t]{3}{*}{ Parameters } & \multicolumn{12}{|l|}{ Dataset } \\
\hline & & \multicolumn{3}{|l|}{ Winter } & \multicolumn{3}{|l|}{ Spring } & \multicolumn{3}{|c|}{ Summer } & \multicolumn{3}{|c|}{ Autumn } \\
\hline & & Jan & Feb & Mar & Apr & May & Jun & Jul & Aug & Sep & Oct & Nov & Dec \\
\hline \multirow[t]{5}{*}{2020} & $\mathrm{SO}_{2}(\mathrm{ppb})$ & 7.00 & 6.22 & 4.72 & 3.39 & 3.83 & 4.53 & 4.33 & 6.05 & 6.56 & 5.78 & 6.33 & 9.67 \\
\hline & $\mathrm{PM}_{2.5}\left(\mu \mathrm{g} \mathrm{m}^{-3}\right)$ & 38.75 & 26.44 & 21.56 & 18.62 & 22.75 & 26.25 & 27.75 & 24.37 & 24.50 & 31.62 & 30.94 & 49.50 \\
\hline & $\mathrm{PM}_{10}\left(\mu \mathrm{g} \mathrm{m}^{-3}\right)$ & 73.69 & 68.88 & 52.37 & 44.44 & 65.44 & 75.57 & 71.75 & 78.00 & 78.19 & 79.94 & 62.63 & 89.12 \\
\hline & $\mathrm{RH}(\%)$ & 57.95 & 46.75 & 41.37 & 48.37 & 26.28 & 17.46 & 21.02 & 26.46 & 23.60 & 32.71 & 57.20 & 67.71 \\
\hline & WS (Knot) & 5.11 & 7.90 & 6.21 & 6.86 & 7.47 & 7.65 & 6.27 & 6.78 & 5.27 & 4.42 & 4.42 & 4.08 \\
\hline
\end{tabular}

(USEPA 1997). In this standard, a maximum concentration of $24 \mathrm{~h}$ was used for $\mathrm{SO}_{2}, \mathrm{PM}_{10}$, and $\mathrm{PM}_{2.5}$.

The instruments used to measure the concentrations of $\mathrm{SO}_{2}, \mathrm{PM}_{10}$ and $\mathrm{PM}_{2.5}$ were continuous automatic analyzers manufactured by Thermo Fisher Scientific Inc. (Waltham, MA, USA) and Teledyne API Inc. (San Diego, CA, USA). The PM monitor was used to measure the concentrations of both $\mathrm{PM}_{10}$ and $\mathrm{PM}_{2.5}$ in ambient air based on light scattering and $\beta$-ray attenuation. The $\mathrm{SO}_{2}$ analyzer employed pulse fluorescence detection to determine the $\mathrm{SO}_{2}$ concentration in the ambient air. Data must be evaluated in the wider context of the checks and calibrations employed during their use and in the production of published data, a process usually known as quality assurance and quality control (QA/QC). Recording Air Quality Control Company systems follows QA/QC (2008/50/EC). Then, in the ArcGIS software, the IDW method was used to obtain air pollution zoning maps. As a result, spatial analysis of distribution of $\mathrm{SO}_{2}, \mathrm{PM}_{2.5}$ and $\mathrm{PM}_{10}$ contaminants in Tehran was made. Also, the Spearman correlation coefficient model was used to examine the relationship between sulfur dioxide and $\mathrm{PM}_{10}, \mathrm{PM}_{2.5}, \mathrm{RH}$, and WS (Ozbay 2012). Correlation coefficients $(r)$ significant at the 0.05 level $(P$ value $\leq 0.05)$ are identified with a single asterisk (significant).

$r=\frac{\sum\left(\hat{y}_{i}-\overline{\hat{y}_{i}}\right)\left(y_{i}-\overline{y_{i}}\right)}{\sqrt{\sum\left(\hat{y}_{i}-\overline{\hat{y}_{i}}\right)^{2} \sum\left(y_{i}-\overline{y_{i}}\right)^{2}}}$

\subsection{ARIMA model}

Time series forecasts including automatic ARIMA modeling was carried out using the 'forecast' package. A differenced process that depends upon the $\mathrm{p}$ lags of the series values and $\mathrm{q}$ lags of the error terms is termed as ARIMA ( $\mathrm{p}=$ autoregressive, $\mathrm{d}=$ differencing, $\mathrm{q}=$ moving average). we apply these processes on this series to find out the best and most appropriate ARIMA model. The ARIMA model can be considered as a "cascade" of the two models. The first part of this model is suitable for non-stationary conditions, the equation of which is as follows:

$Y_{t}=(1-L)^{d} X_{t}$.

The second part is wide-sense stationary, the equation of which is as follows:

$\left(1-\sum_{i=1}^{p} \varphi_{i} L^{i}\right) Y_{t}=\left(1+\sum_{i=1}^{q} \theta_{i} L^{i}\right) \varepsilon_{t}$.

The variables of this equation are: $\mathrm{L}$ is the lag operator, $\theta_{i}$ the parameters of the moving average part, $\varepsilon_{t}$ is error term, and the three variables $\mathrm{p}, \mathrm{d}, \mathrm{q}$ mentioned earlier.

The values of the $p$ and $q$ variables can be found by one of the functions: autocorrelation function (ACF), or partial autocorrelation function (PACF). We used both of these functions here to find the most suitable order (Agrawal et al. 2017). To establish whether an ARIMA model qualifies to predict the concentration of sulfur dioxide, $\mathrm{PM}_{2.5}$ and $\mathrm{PM}_{10}$ and wind Speed and relative humidity parameters in Tehran, statistical errors through determination coefficient $\left(\mathrm{R}^{2}\right)$, mean square error (MSE) and root mean square error (RMSE) were applied as follows (Beckerman et al. 2013; Elavarasan et al. 2018; Goap et al. 2018):

$R^{2}=1-\frac{\sum_{i=1}^{n}\left(y_{i}-\overline{y_{i}}\right)}{\sum_{i=1}^{n}\left(y_{i}-\bar{y}\right)}$

$M S E=\frac{1}{n} \sum_{i=1}^{n}\left(y_{i}-\hat{y}_{i}\right)^{2}$

$R M S E=\sqrt{\frac{1}{n} \sum_{i=1}^{n}\left(y_{i}-\hat{y}_{i}\right)^{2}}$

where $y_{i}$ and $\hat{y}_{i}$ are the forecasted and observed $i$ values of $y, \overline{y_{i}}$ and $\overline{\hat{y}_{i}}$ represent the mean $y$ values of the forecasted and observed in the tested sample set and $n$ denotes the number of datum points in the set. 
Table 2 The average monthly $\mathrm{SO}_{2}, \mathrm{PM}_{2.5}$ and $\mathrm{PM}_{10}$ concentration and $\mathrm{RH}$ and WS in the city Tehran from 2011 to 2020

\begin{tabular}{llllll}
\hline Month & $\mathrm{SO}_{2}(\mathrm{ppb})$ & $\mathrm{PM}_{2.5}\left(\mu \mathrm{g} \mathrm{m}^{-3}\right)$ & $\mathrm{PM}_{10}\left(\mu \mathrm{g} \mathrm{m}^{-3}\right)$ & $\mathrm{RH}(\%)$ & WS (Knot) \\
\hline Jan & 17.01 & 37.32 & 82.77 & 50.37 & 5.39 \\
Feb & 14.84 & 32.30 & 75.70 & 46.93 & 6.19 \\
Mar & 12.35 & 26.55 & 63.47 & 38.52 & 7.44 \\
Apr & 11.30 & 25.30 & 64.72 & 34.53 & 7.17 \\
May & 11.38 & 28.02 & 76.02 & 26.47 & 7.94 \\
Jun & 11.21 & 31.79 & 89.23 & 19.00 & 7.27 \\
Jul & 11.48 & 32.98 & 91.60 & 19.49 & 6.42 \\
Aug & 11.81 & 30.51 & 90.55 & 21.07 & 5.98 \\
Sep & 12.89 & 30.92 & 91.13 & 22.34 & 5.78 \\
Oct & 12.54 & 31.71 & 88.56 & 35.53 & 5.45 \\
Nov & 12.49 & 35.52 & 80.20 & 51.91 & 4.61 \\
Dec & 13.94 & 42.86 & 89.29 & 55.25 & 4.54 \\
\hline
\end{tabular}

In this study, Meteorological data from the Mehrabad synoptic station in Tehran during a period of 10 statistical years (2011-2020) was used to recorded wind speed and relative humidity. Mehrabad Meteorological Station is located at $35^{\circ} 41^{\prime} \mathrm{N}$ and $51^{\circ} 19^{\prime} \mathrm{E}$. The average annual temperature, average annual relative humidity, average annual precipitation, and annual sunshine hours are $17.7{ }^{\circ} \mathrm{C}, 41 \%, 238.9 \mathrm{~mm}$, and $3025 \mathrm{~h}$, respectively. The prevailing wind is from the west, as calculated at three times of record (morning, noon, and evening) at a speed of $5.5 \mathrm{~m} / \mathrm{s}$ (IRIMO 2020).

\section{Result and discussion}

\subsection{Sampling data analysis}

The results show that the trend of changes in $\mathrm{PM}_{2.5}, \mathrm{PM}_{10}$, and sulfur dioxide in Tehran decreased from 2011 to 2020 (Fig. 4a-c) (Skrobacki et al. 2019). Torbatian et al. (2020) investigated air pollution variations in Tehran. Their results show that the $\mathrm{PM}_{2.5}$ and sulfur dioxide concentrations decreased from 2005 to 2016. The average concentrations of $\mathrm{SO}_{2}, \mathrm{PM}_{2.5}$, and $\mathrm{PM}_{10}$ during the last 10 Years, are $12.77 \mathrm{ppb}, 32.14 \mathrm{\mu g} \mathrm{m}^{-3}$ and $81.94 \mu \mathrm{g} \mathrm{m}^{-3}$, respectively. In December and January 2019 and 2020, the concentrations of $\mathrm{PM}_{2.5}, \mathrm{PM}_{10}$, and sulfur dioxide increased (Table 1). It was found that the maximum concentration for the examined period was recorded in January 2012 with an average value of $29.91 \mathrm{ppb}$ and the lowest average monthly concentration for $\mathrm{SO}_{2}$ was in 2018 (3.00 ppb) (Table 1). Sulfur dioxide pollutants also cause the formation of secondary suspended particles in the atmosphere. in winter and autumn, inversion is often observed in the city, which leads to an increase in the concentration of pollutants in the city. Kaushik and Melwani (2007), observed high $\mathrm{SO}_{2}$ concentrations during the colder months in Delhi.
However, in another study in Kerman, Iran, $\mathrm{SO}_{2}$ concentrations were shown to have a stable trend (Mansouri et al. 2013).

In this study, $\mathrm{PM}_{10}$ also showed a decreasing trend. The highest average monthly concentration for $\mathrm{PM}_{10}$ was in $2013\left(112.2 \mathrm{\mu g} \mathrm{m}^{-3}\right)$ and the lowest in 2020 (44.44 $\mathrm{g} \mathrm{m}^{-3}$ ) and maximum values are seen in summer (Table 2). The results described in the present study are consistent with several earlier investigations (Draxler et al. 2001; Shahsavani et al. 2012). According to Fig. 3b, the highest amounts of $\mathrm{PM}_{10}$ were recorded in the Shad Abad station.

The highest average monthly concentrations for $\mathrm{PM}_{2.5}$ were in $2017\left(52.81 \mathrm{\mu g} \mathrm{m}^{-3}\right)$ and the lowest in 2019 $\left(17.00 \mu \mathrm{g} \mathrm{m}^{-3}\right) . \mathrm{PM}_{2.5}$ reaches its maximum concentration in Tehran in December and January (Table 2). Zhang et al. (2021) examining the trend of $\mathrm{PM}_{2.5}$ concentration, they also concluded that the average $\mathrm{PM}_{2.5}$ concentration reaches its maximum in December and January. The zoning map shows that in regions 3 and 18 (Darrous and Shadabad monitoring stations), concentrations of $\mathrm{PM}_{2.5}$ are high and in the central regions is less (Fig. 3a).

Two monitoring stations, Darrous and Aqdasiyeh, are located in the north of the city, and higher sulfur dioxide concentration is observed at these sites. After that, the District 16 monitoring station (in the southwest of Tehran) shows the highest sulfur dioxide concentration (Fig. 3c). The primary and secondary standard for sulfur dioxide according to the NAAQS for $24 \mathrm{~h}$ was $140 \mathrm{ppb}$ (Goudarzi et al. 2014; WHO 2003; US EPA 2011). Table 3 shows that the annual average concentration of sulfur dioxide in air quality monitoring stations in Tehran was below the NAAQS standards from 2011 to 2020. One of the factors that can be effective in the heterogeneous distribution of pollutants in the city of Tehran is the rapid population growth and development of construction activity in some areas compared to other areas. This means that 
Fig. 3 Distribution of annual average concentration in air quality monitoring stations in Tehran from 2011 to 2020, a $\mathrm{PM}_{2.5}$, b $\mathrm{PM}_{10}$, c $\mathrm{SO}_{2}$
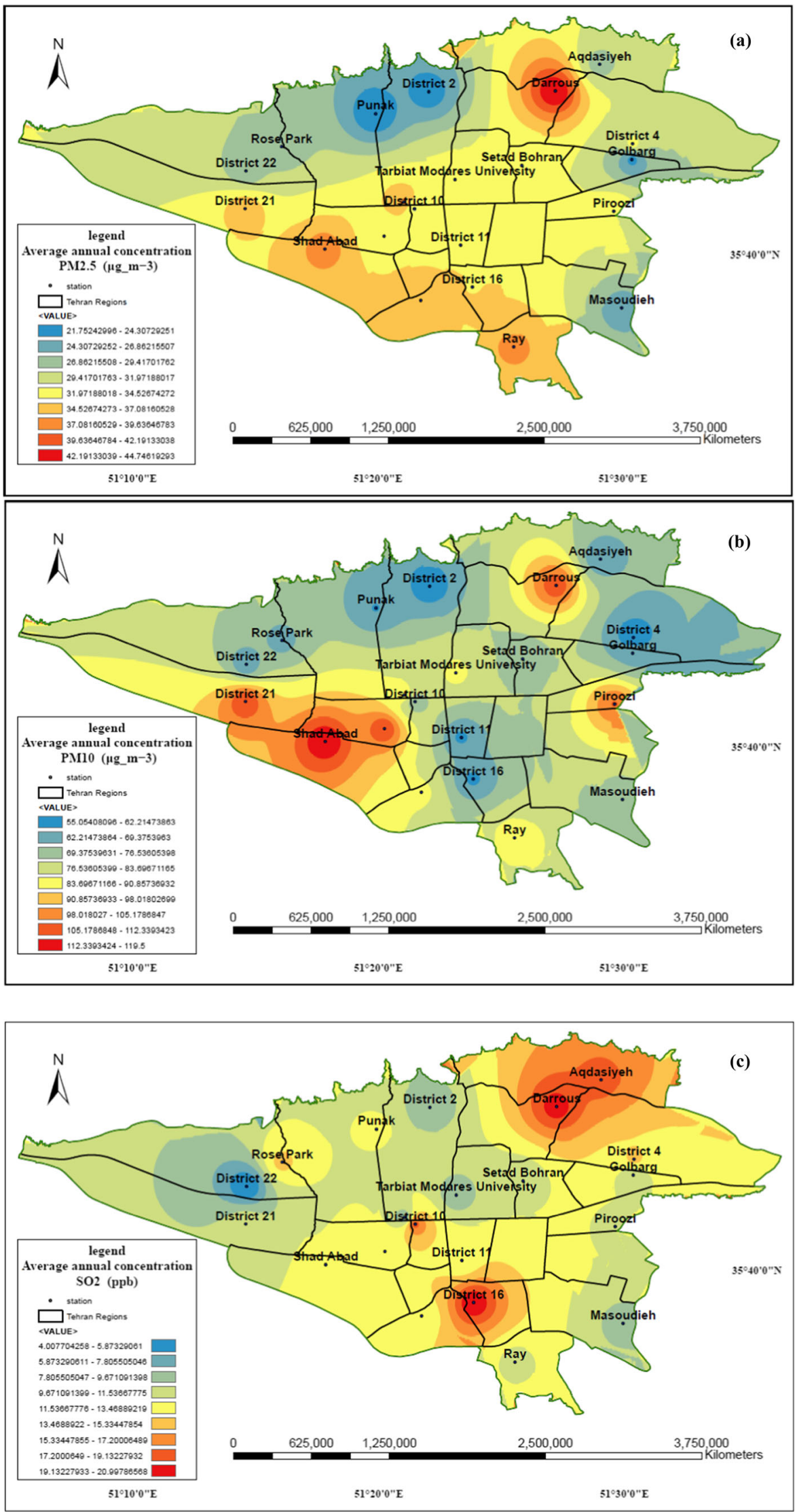
Table 3 Detailed information on AQMSs and the hourly average of $\mathrm{SO}_{2}, \mathrm{PM}_{2.5}$ and $\mathrm{PM}_{10}$ data recorded from 2011 to 2020 in Tehran

\begin{tabular}{|c|c|c|c|c|c|c|c|}
\hline No & District & Air Quality Monitoring Stations (AQMSs) & Latitude & Longitude & $* \mathrm{SO}_{2}(\mathrm{ppb})$ & $* \mathrm{PM}_{2.5}\left(\mu \mathrm{g} \mathrm{m}^{-3}\right)$ & $* \mathrm{PM}_{10}\left(\mu \mathrm{g} \mathrm{m}^{-3}\right)$ \\
\hline 1 & 1 & Aqdasiyeh & 35.7958 & 51.4841 & 18.00 & 28.50 & 64.50 \\
\hline 2 & 2 & Sharif University & 35.7022 & 51.3509 & 8.00 & 37.50 & 88.00 \\
\hline 3 & 20 & Ray & 35.6036 & 51.4257 & 11.00 & 37.50 & 87.00 \\
\hline 4 & 21 & District 21 & 35.6977 & 51.2431 & 11.00 & 36.50 & 111.50 \\
\hline 5 & 5 & Punak & 35.7623 & 51.3316 & 12.00 & 21.75 & 62.00 \\
\hline 6 & 8 & Golbarg & 35.7310 & 51.5061 & 10.00 & 23.50 & 68.00 \\
\hline 7 & 15 & Masoudieh & 35.6300 & 51.4990 & 9.00 & 25.75 & 73.00 \\
\hline 8 & 6 & Tarbiat Modares University & 35.7175 & 51.3859 & 8.00 & 32.75 & 85.50 \\
\hline 9 & 10 & District 10 & 35.6974 & 51.3580 & 18.00 & 31.75 & 71.00 \\
\hline 10 & 9 & Fath.Square & 35.6788 & 51.3375 & 13.00 & 32.75 & 112.00 \\
\hline 11 & 7 & Setad Bohran & 35.7270 & 51.4312 & 10.00 & 32.25 & 72.00 \\
\hline 12 & 19 & District 19 & 35.6352 & 51.3625 & 12.00 & 36.50 & 85.00 \\
\hline 13 & 18 & Shad Abad & 35.6700 & 51.2973 & 12.00 & 38.50 & 119.50 \\
\hline 14 & 22 & District 22 & 35.7233 & 51.2436 & 4.00 & 27.50 & 64.00 \\
\hline 15 & 16 & District 16 & 35.6445 & 51.3976 & 21.00 & 34.50 & 61.00 \\
\hline 16 & 13 & Piroozi & 35.6959 & 51.4937 & 11.00 & 33.75 & 105.50 \\
\hline 17 & 2 & District 2 & 35.7770 & 51.3681 & 8.00 & 22.75 & 58.00 \\
\hline 18 & 11 & District 11 & 35.6729 & 51.3897 & 12.00 & 34.25 & 61.00 \\
\hline 19 & 22 & Rose Park & 35.7398 & 51.2678 & 14.00 & 27.75 & 67.00 \\
\hline 20 & 4 & District 4 & 35.7418 & 51.5064 & 14.00 & 32.75 & 55.00 \\
\hline 21 & 3 & Darrous & 35.7777 & 51.4541 & 20.00 & 44.75 & 110.00 \\
\hline
\end{tabular}

*Air Quality Monitoring Stations with less than 75\% valid hourly data available were excluded from the next analysis

Table 4 Spearman's rank correlations between $\mathrm{SO}_{2}$, $\mathrm{PM}_{2.5}, \mathrm{PM}_{10}$ and $\mathrm{RH}$, WS data from 2011 to 2020

\begin{tabular}{llllll}
\hline & $\mathrm{SO}_{2}(\mathrm{ppb})$ & $\mathrm{PM}_{2.5}\left(\mu \mathrm{g} \mathrm{m}^{-3}\right)$ & $\mathrm{PM}_{10}\left(\mu \mathrm{g} \mathrm{m}^{-3}\right)$ & $\mathrm{RH}(\%)$ & WS (Knot) \\
\hline $\mathrm{SO}_{2}(\mathrm{ppb})$ & 1 & & & & \\
$\mathrm{PM}_{2.5}\left(\mu \mathrm{g} \mathrm{m}^{-3}\right)$ & 0.5787 & 1 & & & \\
$\mathrm{PM}_{10}\left(\mu \mathrm{g} \mathrm{m}^{-3}\right)$ & 0.0648 & 0.5611 & 1 & & \\
$\mathrm{RH}(\%)$ & 0.6845 & 0.5679 & $-0.2986^{*}$ & 1 & 1 \\
WS (Knot) & $-0.5186^{*}$ & $-0.8083^{*}$ & $-0.4960^{*}$ & $-0.5873^{*}$ & 1 \\
\hline
\end{tabular}

$* P \leq 0.05$
Table 5 Square root of the MSE for Algorithm test the average monthly $\mathrm{SO}_{2}, \mathrm{PM}_{2.5}$ and $\mathrm{PM}_{10}$ concentration and $\mathrm{RH}$ and WS in Tehran from January 2020 to December 2020

\begin{tabular}{lllllll}
\hline No & Models $(\mathrm{p}, \mathrm{d}, \mathrm{q})$ & $\mathrm{RMSE} \mathrm{SO}_{2}$ & RMSE PM $_{2.5}$ & RMSE PM $_{10}$ & RMSE WS & RMSE RH \\
\hline 1 & ARIMA $(1,1,1)$ & 3.6331 & 8.6379 & 15.0551 & 2.1165 & Error \\
2 & ARIMA $(2,1,2)$ & 3.7908 & 7.1540 & 17.9815 & 1.4282 & 8.9558 \\
3 & ARIMA $(3,1,3)$ & 3.8052 & 8.4443 & 14.6274 & $0.7193^{*}$ & Error \\
4 & ARIMA $(3,2,3)$ & 1.9937 & 20.8813 & $14.4223^{*}$ & 2.8032 & Error \\
5 & ARIMA $(4,1,4)$ & 1.5600 & 7.6312 & 16.9547 & Error & Error \\
6 & ARIMA $(3,1,4)$ & $1.5172^{*}$ & 7.8734 & 14.8090 & Error & $8.6740^{*}$ \\
7 & ARIMA $(2,1,4)$ & 3.7239 & 7.7383 & 14.5312 & 0.9204 & 8.7141 \\
8 & ARIMA $(2,1,3)$ & Error & $7.0851^{*}$ & 14.5628 & 1.3185 & Error \\
\hline
\end{tabular}

MSE Mean squared error, RMSE Square root of the MSE, Error The algorithm has not reached convergence *Minimum square root of the MSE 
Table 6 Comparison of model predictions and actual values for average monthly $\mathrm{SO}_{2}, \mathrm{PM}_{2.5}$ and $\mathrm{PM}_{10}$ concentration and $\mathrm{RH}$ and WS in Tehran from January 2020 to December 2020 (Algorithm test)

\begin{tabular}{|c|c|c|c|c|c|c|c|c|c|c|}
\hline \multirow[t]{2}{*}{ Month } & \multicolumn{2}{|c|}{$\mathrm{SO}_{2}(\mathrm{ppb})$} & \multicolumn{2}{|c|}{$\mathrm{PM}_{2.5}\left(\mu \mathrm{g} \mathrm{m}^{-3}\right)$} & \multicolumn{2}{|c|}{$\mathrm{PM}_{10}\left(\mu \mathrm{g} \mathrm{m}^{-3}\right)$} & \multicolumn{2}{|c|}{ WS (Knot) } & \multicolumn{2}{|c|}{$\mathrm{RH}(\%)$} \\
\hline & AV & PV & AV & PV & AV & PV & AV & PV & AV & PV \\
\hline Jan & 7.00 & 6.08 & 38.75 & 39.59 & 73.69 & 85.31 & 5.11 & 5.56 & 57.95 & 51.37 \\
\hline $\mathrm{Feb}$ & 6.22 & 5.15 & 26.44 & 29.46 & 68.88 & 79.06 & 7.90 & 6.10 & 46.75 & 48.88 \\
\hline Mar & 4.72 & 4.78 & 21.56 & 23.56 & 52.37 & 77.73 & 6.21 & 6.71 & 41.37 & 42.45 \\
\hline Apr & 3.39 & 4.84 & 18.62 & 24.63 & 44.44 & 76.61 & 6.86 & 7.12 & 48.37 & 33.81 \\
\hline May & 3.83 & 5.15 & 22.75 & 28.30 & 64.44 & 77.51 & 7.47 & 7.22 & 26.28 & 25.25 \\
\hline Jun & 4.53 & 5.53 & 26.25 & 30.20 & 75.57 & 77.49 & 7.65 & 7.00 & 17.46 & 19.05 \\
\hline Jul & 4.33 & 5.83 & 27.75 & 29.57 & 71.75 & 78.05 & 6.27 & 6.50 & 21.02 & 16.85 \\
\hline Aug & 6.05 & 6.01 & 24.37 & 28.12 & 78.00 & 77.93 & 6.78 & 5.87 & 26.46 & 19.23 \\
\hline Sep & 6.56 & 6.03 & 24.50 & 27.39 & 78.19 & 78.17 & 5.27 & 5.26 & 23.60 & 25.57 \\
\hline Oct & 5.78 & 5.91 & 31.62 & 27.57 & 79.94 & 78.09 & 4.42 & 4.85 & 32.71 & 34.15 \\
\hline Nov & 6.33 & 5.70 & 30.94 & 28.01 & 62.63 & 78.27 & 4.42 & 4.74 & 57.20 & 42.70 \\
\hline Dec & 9.67 & 5.45 & 49.50 & 28.16 & 89.12 & 78.27 & 4.08 & 4.97 & 67.71 & 48.93 \\
\hline
\end{tabular}

$A V$ Actual value, $P V$ Predicted value development has not been continuously distributed throughout the city during these ten years.

\subsection{Correlation analysis}

Table 4 shows the relationships between sulfur dioxide and $\mathrm{PM}_{2.5}, \mathrm{PM}_{10}$, RH, WS using the average Pearson correlation coefficient (r). The results indicated that the Sulfur oxides, in combination with particulate matter and relatively high relative humidity, have the strongest negative impact on the environment $(P$ value $>0.05)$ (Schwartz 1996; Asadifard 2013). While the concentration of sulfur oxides decreases with increasing wind speed $(P$ value $<0.05)$ (Unal et al. 2000). Venners et al. (2003) also investigated the concentration of sulfur oxides in Chongqing, China, showing that there is a positive correlation between sulfur dioxide concentrations and particulates (either $\mathrm{PM}_{2.5}$ and $\mathrm{PM}_{10}$ ) concentrations. wind speed (WS) has a negative correlation with $\mathrm{PM}_{2.5}$ and $\mathrm{PM}_{10}$ concentrations ( $r=-0.808$ and -0.496 respectively). In addition, a significant positive correlation was observed between $\mathrm{PM}_{2.5}$ and $\mathrm{PM}_{10}$, which shows that $\mathrm{PM}_{2.5}$ and $\mathrm{PM}_{10}$ have the same origin $(r=0.561)$.

\subsection{Results of the ARIMA model}

For the purpose of time series modelling in this study, the first 12 observations (January 2020 to December 2020) were used to fit the ARIMA model while the subsequent 7 observations (from January 2021 to July 2021) were kept for the post sample forecast accuracy check. As presented in Table 5, the value of $\mathrm{SO}_{2}$ is decreases till the ARIMA $(3,1,4)$ but at ARIMA $(2,1,4)$ it again increases. So, the smallest significant value of $\mathrm{SO}_{2}$ for the ARIMA process is at ARIMA $(3,1,4)$. So, we may conclude that the ARIMA $(3,1,4)$ gives better results on forecasting the concentration of sulfur dioxide. Pohoata and Lungu (2017) also used the ARIMA model to forecast $\mathrm{SO}_{2}$ concentration in Ploiesti, Romania, showing that the best result was obtained with ARIMA (3, 1, 3). Das et al. (2019) also showed the best fitted ARIMA ( $p, d, q$ ) was selected on the basis of the maximum value of $R^{2}$ and minimum value of RMSE. Similarly, ARIMA (2, 1, 3), ARIMA (3, 2, 3), ARIMA $(3,1,4)$ and ARIMA $(3,1,3)$ are the best model for predicting the concentration of $\mathrm{PM}_{2.5}, \mathrm{PM}_{10}$, relative humidity and wind speed, respectively. The ARIMA model was able to predict the 7 months from 2021 relatively accurately, with only 1 year (2020) of data (Table 6). The ARIMA statistical forecasting method did not provide satisfactory results to predict $\mathrm{PM}_{10}$ concentrations in 2021, the relative errors are bigger than $10 \%$ (Fig. 4c). The forecasting of the $\mathrm{PM}_{10}$ concentrations is difficult because of the uncertainties in describing the meteorological conditions and emission variability (Zhang et al. 2017). This error rate may be associated with a rapid change in wind direction. The prevailing wind flows from the west in Tehran. main winds from west, south and southwest which are industrial places are the main sources of Tehran air pollution (Borhani et al. 2017, 2021b). The increasing error in forecasting is due to the unpredictability of new trends that may occur in the future. In April 2021 prediction for $\mathrm{SO}_{2}$ concentration, the Actual Value was $4.68 \mathrm{ppb}$, while the Predicted Value was $4.61 \mathrm{ppb}$, a difference of $0.07 \mathrm{ppb}$. For the data corresponding to $\mathrm{SO}_{2}, \mathrm{PM}_{2.5}$, WS and RH time series, the determination coefficient $\left(\mathrm{R}^{2}\right)$ and RMSE equal to $(0.74,2.18),(0.73,9.49),(0.88,0.67)$ and $(0.82,9.66)$, respectively (as can be seen in Fig. $4 \mathrm{a}-\mathrm{e}$ and 

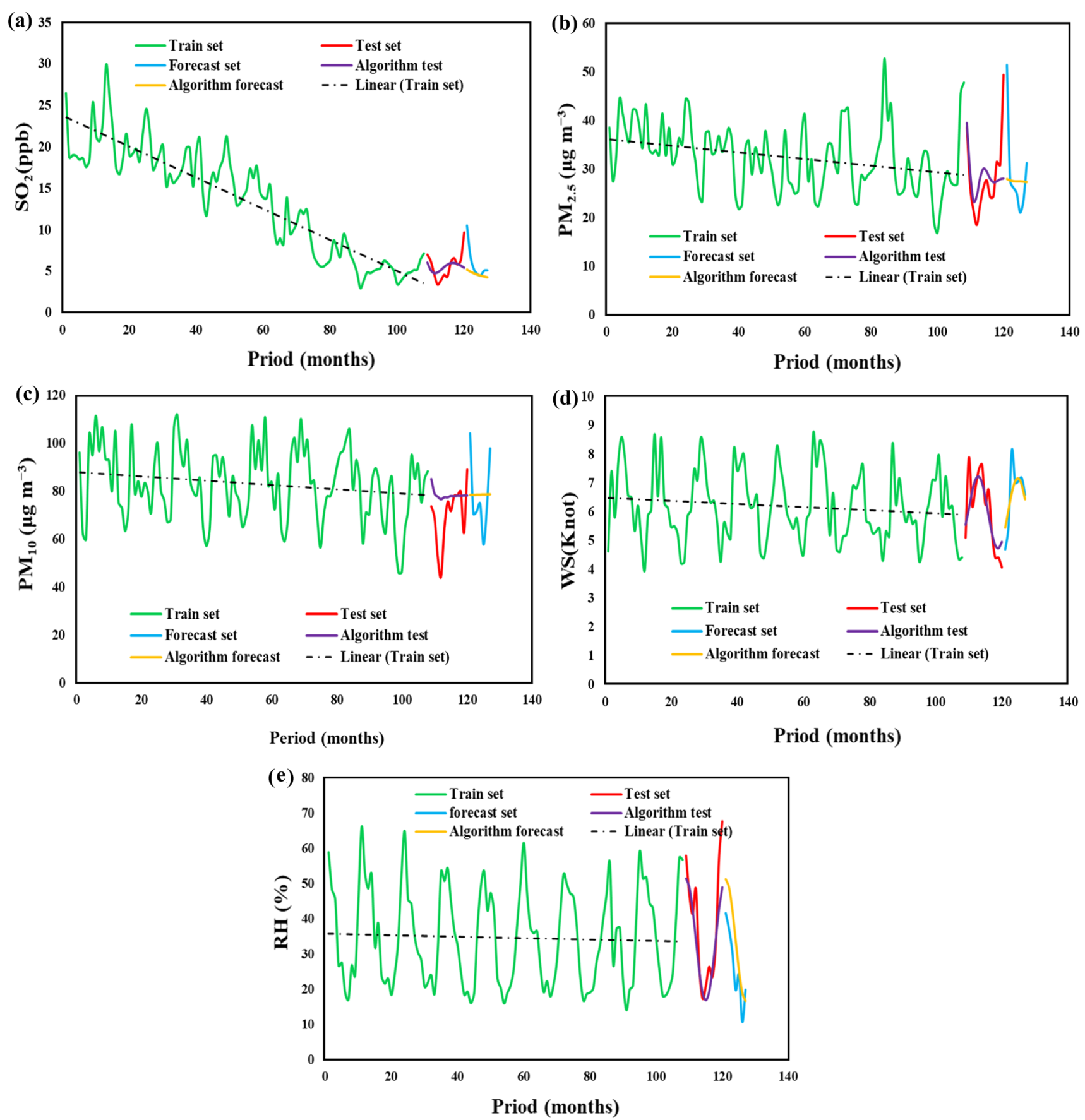

Fig. 4 Time-series analysis (Train set,Forecast set, Algorithm forecast, Test set and Algorithm test) model in air quality monitoring stations in Tehran from 2011 to 2020 , a $\mathrm{SO}_{2}, \mathbf{b} \mathrm{PM}_{2.5}$, c $\mathrm{PM}_{10}$, d WS, e RH

Table 7). Therefore, the ARIMA model provided satisfactory results.

In general, the ARIMA model is the most suitable model for predicting unexpected values, but drastic changes in the data and, of course, the monthly step and averaging have caused a high error for some pollutants, even when the noise has been removed.

\section{Conclusion}

The paper presents the results of comparative analysis of measuring and monitoring the concentration of sulfur dioxide, based on, the changes in sulfur dioxide concentration due to changes in particulates (either $\mathrm{PM}_{10}$ and $\mathrm{PM}_{2.5}$ ) concentrations and meteorological conditions (relative humidity and wind speed) in the air in the city of 
Table 7 Comparison of model predictions and actual values for average monthly $\mathrm{SO}_{2}, \mathrm{PM}_{2.5}$ and $\mathrm{PM}_{10}$ concentration and $\mathrm{RH}$ and WS in Tehran from January 2021 to July 2021 (Algorithm forecast)

\begin{tabular}{|c|c|c|c|c|c|c|c|c|c|c|}
\hline \multirow[t]{2}{*}{ Month } & \multicolumn{2}{|c|}{$\mathrm{SO}_{2}(\mathrm{ppb})$} & \multicolumn{2}{|c|}{$\mathrm{PM}_{2.5}\left(\mu \mathrm{g} \mathrm{m}^{-3}\right)$} & \multicolumn{2}{|c|}{$\mathrm{PM}_{10}\left(\mu \mathrm{g} \mathrm{m}^{-3}\right)$} & \multicolumn{2}{|c|}{ WS (Knot) } & \multicolumn{2}{|c|}{ RH (\%) } \\
\hline & $\mathrm{AV}$ & PV & $\mathrm{AV}$ & PV & AV & PV & AV & PV & AV & PV \\
\hline Jan & 10.53 & 5.19 & 51.47 & 27.98 & 104.12 & 78.41 & 4.70 & 5.46 & 41.60 & 51.18 \\
\hline Feb & 6.84 & 4.96 & 27.65 & 27.72 & 70.63 & 78.44 & 5.51 & 6.08 & 37.00 & 48.84 \\
\hline Mar & 5.26 & 4.76 & 26.23 & 27.58 & 71.75 & 78.56 & 8.15 & 6.68 & 30.70 & 42.54 \\
\hline Apr & 4.68 & 4.61 & 25.00 & 27.56 & 74.81 & 78.61 & 7.02 & 7.09 & 19.80 & 33.95 \\
\hline May & 4.47 & 4.49 & 21.18 & 27.55 & 57.81 & 78.71 & 7.07 & 7.18 & 24.20 & 25.35 \\
\hline Jun & 5.05 & 4.39 & 23.67 & 27.51 & 72.69 & 78.77 & 7.18 & 6.94 & 10.70 & 19.03 \\
\hline Jul & 5.10 & 4.29 & 31.33 & 27.42 & 97.94 & 78.86 & 6.59 & 6.44 & 19.90 & 16.67 \\
\hline $\mathrm{R}^{2}$ & 0.74 & & 0.73 & & 0.10 & & 0.88 & & 0.82 & \\
\hline RMSE & 2.18 & & 9.49 & & 15.22 & & 0.67 & & 9.66 & \\
\hline
\end{tabular}

$A V$ Actual value, $P V$ Predicted value, $R^{2}$ Determination coefficient
Tehran from 2011 to 2020. In this study used an ARIMA modelling approach for short-term forecasting Sulfur dioxide $\left(\mathrm{SO}_{2}\right)$, Particulate Matter $\left(\mathrm{PM}_{10}\right.$ and $\left.\mathrm{PM}_{2.5}\right)$ concentrations, and meteorological conditions (relative humidity and wind speed). According to the measurements results of $\mathrm{SO}_{2}, \mathrm{PM}_{10}$ and $\mathrm{PM}_{2.5}$ concentrations from 21 monitoring stations of Air Quality Control Company in Tehran and the data of Mehrabad Meteorological Station (RH and WS), it can be deduced, average $\mathrm{SO}_{2}, \mathrm{PM}_{10}$, and $\mathrm{PM}_{2.5}$ concentrations have decreased significantly over the past decade. And as for the seasonal concentrations, $\mathrm{SO}_{2}$ concentrations in the air are increased in the winter, which is affected not only by weather but also by other pollutants (production of thermal energy for city heating, combustion of fuel oil in power plants, small boiler rooms for certain economic entities, companies, old vehicles, etc.). The results show that the monthly concentration of sulfur dioxide is lowest in June and highest in January. The distribution of annual average concentration in air quality monitoring stations shows that the highest average $\mathrm{SO}_{2}$ concentration in zoning map is related to the north and southwest of Tehran. The Correlations of $\mathrm{SO}_{2}$ with $\mathrm{PM}_{2.5}$ and $\mathrm{PM}_{10}$ and with relative humidity and wind speed were examined using Pearson correlation. The results showed that $\mathrm{SO}_{2}$ has a positive and significant correlation with $\mathrm{PM}_{2.5}, \mathrm{PM}_{10}$ and relative humidity and a negative correlation with relative wind speed. These results come from the fact that more than $80 \%$ of sulfur oxides are produced by burning fossil fuels from stationary pollution sources, followed by the most important cause of particulate matter emissions, the high volume of traffic in Tehran. The Alborz Mountains have made Tehran's climate very humid and as a result, sulfur oxides combined with suspended particulate matter and humidity have the most harmful effects on air pollution in Tehran.

However, for quality improvement, it is necessary to take many additional measures, such as the expansion of the public transport system, especially the metro system, the establishment of technical control centers and the obligation of technical inspection of vehicles, the control and monitoring of car traffic, especially in the last hours of the night, the change of fuel consumption of suburban power plants and the monitoring of pollution standards, and better distribution of fuel for intercity buses, because without this update, no concrete measures can be taken to reduce $\mathrm{SO}_{2}$.

In addition, relatively accurate prediction of air pollutant concentrations, both short and long term, is an important step in mitigating the damage causes of poor air quality. For example, public and private institutions can plan for the economic, health and environmental impacts of air pollution by predicting the period when air pollution levels may be particularly high.

Acknowledgements Special thanks are extended to Tehran Air Quality Control Company (AQCC), Department of Environment (DOE) and Iran Meteorological Organization (IRIMO) for efficient help in providing the database of this study.

Author contributions FB (Conception or design of the work, Data collection, Data analysis and interpretation, Drafting the article and Final approval of the version to be published), MSM (Conception or design of the work, Critical revision of the article and Final approval of the version to be published), YR (Data collection and Final approval of the version to be published), AHE (Data collection and Final approval of the version to be published).

Funding The authors did not receive support from any organization for the submitted work.

Data availability The database analyzed during the present study are available from the corresponding author on reasonable request.

\section{Declarations}

Conflict of interest The authors declare that they have no known competing financial interests or personal relationships that could have appeared to influence the work reported in this paper. 
Consent to participate Informed consent was obtained from all individual participants included in the study.

Consent for publication The authors declare that they agree with the publication of this paper in this journal.

\section{References}

Agrawal KP, Garg S, Sharma S, Patel P, Bhatnagar A (2017) Fusion of statistical and machine learning approaches for time series prediction using earth observation data. Int J Comput Sci Eng 14(3):255-266. https://doi.org/10.1504/IJCSE.2017.084159

Asadifard E (2013) Study of air pollution and its relationship with meteorological parameters in Ahvaz city. Project of B.Sc. degree in Shiraz University

Beckerman BS, Jerrett M, Martin RV, van Donkelaar A, Ross Z, Burnett RT (2013) Application of the deletion/substitution/ addition algorithm to selecting land use regression models for interpolating air pollution measurements in California. Atmos Environ 77:172-177. https://doi.org/10.1016/j.atmosenv.2013. 04.024

Bhatti UA, Yan Y, Zhou M, Ali S, Hussain A, Qingsong H, Yuan L (2021) Time series analysis and forecasting of air pollution particulate matter $\left(\mathrm{PM}_{2.5}\right)$ : an SARIMA and factor analysis approach. IEEE Access 9:41019-41031. https://doi.org/10.1109/ ACCESS.2021.3060744

Borhani F, Mirmohammadi M, Aslemand A (2017) Experimental study of benzene, toluene, ethylbenzene and xylene (BTEX) concentrations in the air pollution of Tehran, Iran. J Res Environ Health 3(2):105-115. https://doi.org/10.22038/jreh.2017.23688. 1151

Borhani F, Noorpoor A (2020) Measurement of air pollution emissions from chimneys of production units moisture insulation (Isogam) Delijan. J Environ Sci Technol 21(12):57-71. https:// doi.org/10.22034/jest.2020.25934.3488

Borhani F, Motlagh MS, Stohl A, Rashidi Y, Ehsani AH (2021a) Changes in short-lived climate pollutants during the COVID-19 pandemic in Tehran, Iran. Environ Monit Assess 193(6):1-12. https://doi.org/10.1007/s10661-021-09096-w

Borhani F, Shafiepour Motlagh M, Stohl A, Rashidi Y, Ehsani AH (2021b) Tropospheric Ozone in Tehran, Iran, during the last 20 years. Environ Geochem Health. https://doi.org/10.1007/s10653021-01117-4

Braga A, Barbosa S, Farhat S, Martins L, Pereira L, Saldiva P, Zanobetti A (2006) The expanding burden of air pollution on health: the case of sickle cell disease. Epidemiology 17(6):S223S224. https://doi.org/10.1097/00001648-200611001-00571

Das SS, Ray S, Sen A, Siva GS, Das S (2019) Statistical study on modeling and forecasting of jute production in West Bengal, India. Int J Curr Microbiol Appl Sci 8(7):1719-1730. https://doi. org/10.20546/ijcmas.2019.807.204

Draxler RR, Gillette DA, Kirkpatrick JS, Heller J (2001) Estimating $\mathrm{PM}_{10}$ air concentrations from dust storms in Iraq, Kuwait and Saudi Arabia. Atmos Environ 35(25):4315-4330. https://doi.org/ 10.1016/S1352-2310(01)00159-5

Dutkiewicz VA, Das M, Husain L (2000) The relationship between regional $\mathrm{SO}_{2}$ emissions and downwind aerosol sulfate concentrations in the northeastern US. Atmos Environ 34(11):1821-1832. https://doi.org/10.1016/S13522310(99)00334-9

Elavarasan D, Vincent DR, Sharma V, Zomaya AY, Srinivasan K (2018) Forecasting yield by integrating agrarian factors and machine learning models: a survey. Comput Electron Agric 155:257-282. https://doi.org/10.1016/j.compag.2018.10.024
Elminir HK (2005) Dependence of urban air pollutants on meteorology. Sci Total Environ 350(1-3):225-237. https://doi.org/10. 1016/j.scitotenv.2005.01.043

EPA (2008) Integrated Science Assessment (ISA) for sulfur oxideshealth criteria. Rep. EPA/600/R-08/047F

Geravandi S, Goudarzi G, Mohammadi MJ, Taghavirad SS, Salmanzadeh S (2015) Sulfur and nitrogen dioxide exposure and the incidence of health endpoints in Ahvaz, Iran. Health Scope. https://doi.org/10.17795/jhealthscope-24318

Goap A, Sharma D, Shukla AK, Krishna CR (2018) An IoT based smart irrigation management system using Machine learning and open source technologies. Comput Electron Agric 155:41-49. https://doi.org/10.1016/j.compag.2018.09.040

Gonçalves FL, Carvalho LMV, Conde FC, Latorre MRDO, Saldiva PHN, Braga ALF (2005) The effects of air pollution and meteorological parameters on respiratory morbidity during the summer in Sao Paulo City. Environ Int 31(3):343-349. https:// doi.org/10.1016/j.envint.2004.08.004

Goudarzi G, Geravandi S, Salmanzadeh S, Zallaghi E (2014) The number of myocardial infarction and cardiovascular death cases associated with sulfur dioxide exposure in Ahvaz, Iran. Arch Hyg. Sci. 3(3):112-119

Happo M (2009) Inflammation and tissue damage in the mouse lung by size-segregated urban air particulate matter: role of chemical composition and sources of particles. National Institute for Health and Welfare, Kuopio, Finland, p 79

Hoveidi H, Aslemand A, Borhani F, Naghadeh SF (2017) Emission and health costs estimation for air pollutants from municipal solid waste management scenarios, case study: NOx and SOx pollutants, Urmia, Iran. J Environ Treat Tech 5(1):59-64

Iran Meteorological Organization, IRIMO (2020) https://www.irimo. ir/

Kalkstein LS, Corrigan P (1986) A synoptic climatological approach for geographical analysis: assessment of sulfur dioxide concentrations. Ann Assoc Am Geogr 76(3):381-395. https://doi.org/ 10.1111/j.1467-8306.1986.tb00126.x

Kaushik I, Melwani R (2007) Time series analysis of ambient air quality at ito intersection in Delhi (India). J Environ Res Dev 2:268-272

Kindbom K, Nielsen OK, Saarinen K, Jónsson K, Aasestad K (2019) Policy brief-emissions of short-lived climate pollutants (SLCP): Emission factors, scenarios and reduction potentials. Nordic Council of Ministers

Krotkov NA, McLinden CA, Li C, Lamsal LN, Celarier EA, Marchenko SV, Streets DG (2016) Aura OMI observations of regional $\mathrm{SO}_{2}$ and $\mathrm{NO}_{2}$ pollution changes from 2005 to 2015 . Atmos Chem Phys 16(7):4605-4629. https://doi.org/10.5194/ acp-16-4605-2016

Losacco C, Perillo A (2018) Particulate matter air pollution and respiratory impact on humans and animals. Environ Sci Pollut Res 25(34):33901-33910. https://doi.org/10.1007/s11356-018$3344-9$

Mansouri F, Khanjani N, Pourmousa R (2013) Forecasting ambient air pollutants by time series models in Kerman, Iran. J Sch Public Health Inst Public Health Res 11(2):75-86

Mallik C, Lal S (2014) Seasonal characteristics of $\mathrm{SO}_{2}, \mathrm{NO}_{2}$, and $\mathrm{CO}$ emissions in and around the Indo-Gangetic Plain. Environ Monit Assess 186(2):1295-1310. https://doi.org/10.1007/s10661-0133458-y

Masoudi M, Behzadi F, Sakhaei M (2018) Status and prediction of sulfur dioxide as an air pollutant in Tehran, Iran. EQA-Int J Environ Qual 28:13-23. https://doi.org/10.6092/issn.2281-4485/ 7420

Moldan F, Wright RF, Löfgren S, Forsius M, Ruoho-Airola T, Skjelkvåle BL (2001) Long-term changes in acidification and recovery at nine calibrated catchments in Norway, Sweden and 
Finland. Hydrol Earth Syst Sci 5(3):339-350. https://doi.org/10. 5194/hess-5-339-2001

Naseem F, Rashid A, Izhar T, Khawar MI, Bano S, Ashraf A, Adnan MN (2018) An integrated approach to air pollution modeling from climate change perspective using ARIMA forecasting. J Appl Agric Biotechnol 2(2):37-44

Özbay B (2012) Modeling the effects of meteorological factors on $\mathrm{SO}_{2}$ and $\mathrm{PM}_{10}$ concentrations with statistical approaches. CleanSoil Air Water 40(6):571-577. https://doi.org/10.1002/clen. 201100356

Pereira L, Braga A, Morimoto T, Braga L, Andre PA, Saldiva P (2009) Association between low birthweight and air pollution in an industrial Brazilian city. Epidemiology 20(6):S82. https://doi. org/10.1097/01.ede.0000362955.25009.82

Pohoata A, Lungu E (2017) A complex analysis employing ARIMA model and statistical methods on air pollutants recorded in Ploiesti. Romania. Rev. Chim. 68(4):818-823. https://doi.org/10. 37358/RC.17.4.5559

Randall S (2008) Baseline assessment of short-lived climate pollutants in Bangladesh. In: Proceedings of 3rd international conference on environmental aspects of Bangladesh, p 33

Retama A, Baumgardner D, Raga GB, McMeeking GR, Walker JW (2015) Seasonal trends in black carbon properties and copollutants in Mexico City. Atmos Chem Phys Discuss 15(8):12539-12582. https://doi.org/10.5194/acpd-15-125392015

Schwartz J (1996) Air pollution and hospital admissions for respiratory disease. Epidemiology 7(1):20-28

Shahsavani A, Naddafi K, Haghighifard NJ, Mesdaghinia A, Yunesian M, Nabizadeh R, Goudarzi G (2012) The evaluation of $\mathrm{PM}_{10}, \mathrm{PM}_{2.5}$, and $\mathrm{PM}_{1}$ concentrations during the Middle Eastern Dust (MED) events in Ahvaz, Iran, from April through September 2010. J Arid Environ 77:72-83. https://doi.org/10. 1016/j.jaridenv.2011.09.007

Sharma BK, Kaur H (2001) An introduction to environmental pollution, vol 456. Krishna Prakashan Media (p) Ltd

Shen J, Valagolam D, McCalla S (2020) Prophet forecasting model: a machine learning approach to predict the concentration of air pollutants $\left(\mathrm{PM}_{2.5}, \mathrm{PM}_{10}, \mathrm{O}_{3}, \mathrm{NO}_{2}, \mathrm{SO}_{2}, \mathrm{CO}\right)$ in Seoul, South Korea. PeerJ 8:e9961. https://doi.org/10.7717/peerj.9961

Skrobacki Z, Dabek LE, Lagowski P (2019) Modelling and forecasting of $\mathrm{SO}_{2}$ concentration in atmospheric air-a case study of the city of Krakow. In: IOP conference series: materials science and engineering, vol 471, no 10, p 102057. IOP Publishing. https:// doi.org/10.1088/1757-899X/471/10/102057

Stohl A, Aamaas B, Amann M, Baker L, Bellouin N, Berntsen TK, Boucher O, Cherian R, Collins W, Daskalakis N, Dusinska M (2015) Evaluating the climate and air quality impacts of shortlived pollutants. Atmos Chem Phys 15(18):10529-10566. https://doi.org/10.5194/acp-15-10529-2015

Tehran Air Quality Control Company, AQCC (2020). http://air. tehran.ir/

Torbatian S, Hoshyaripour A, Shahbazi H, Hosseini V (2020) Air pollution trends in Tehran and their anthropogenic drivers. Atmos Pollut Res 11(3):429-442. https://doi.org/10.1016/j.apr. 2019.11.015

Turalığlu FS, Nuhoğlu A, Bayraktar H (2005) Impacts of some meteorological parameters on $\mathrm{SO}_{2}$ and TSP concentrations in Erzurum, Turkey. Chemosphere 59(11):1633-1642. https://doi. org/10.1016/j.chemosphere.2005.02.003
Unal YS, Incecik S, Borhan Y, Mentes S (2000) Factors influencing the variability of $\mathrm{SO}_{2}$ concentrations in Istanbul. J Air Waste Manag Assoc 50(1):75-84. https://doi.org/10.1080/10473289. 2000.10463981

US EPA (1997) United States Environmental Protection Agency. 1993. Analysis of the impacts of control programs on motor vehicle toxic emissions and exposure nationwide, volume IUS Environmental Protection Agency, Office of Transportation and Air Quality

US EPA, Air Quality Index, AQI (2011) A guide to air quality and your health. 9 December 2011. Accepted 8 Aug 2012

Venners SA, Wang B, Xu Z, Schlatter Y, Wang L, Xu X (2003) Particulate matter, sulfur dioxide, and daily mortality in Chongqing, China. Environ Health Perspect 111(4):562-567. https://doi.org/10.1289/ehp.5664

Wang P, Cao J, Tie X, Wang G, Li G, Hu T, Zhan C (2015) Impact of meteorological parameters and gaseous pollutants on $\mathrm{PM}_{2.5}$ and $\mathrm{PM}_{10}$ mass concentrations during 2010 in Xi' an, China. Aerosol Air Qual Res 15(5):1844-1854. https://doi.org/10.4209/aaqr. 2015.05.0380

Wei T, Tang M (2018) Biological effects of airborne fine particulate matter $\left(\mathrm{PM}_{2.5}\right)$ exposure on pulmonary immune system. Environ Toxicol Pharmacol 60:195-201. https://doi.org/10.1016/j.etap. 2018.04.004

WHO, World Health Organization (2003) Health aspects of air pollution with particulate matter, ozone and nitrogen dioxide: report on a WHO working group, Bonn, Germany 13-15 January 2003 (No. EUR/03/5042688). WHO Regional Office for Europe, Copenhagen

Wu X, Nethery RC, Sabath BM, Braun D, Dominici F (2020) Exposure to air pollution and COVID-19 mortality in the United States. MedRxiv. https://doi.org/10.1101/2020.04.05.20054502

Yun Y, Gao R, Yue H, Li G, Zhu N, Sang N (2015) Synergistic effects of particulate matter $\left(\mathrm{PM}_{10}\right)$ and $\mathrm{SO}_{2}$ on human nonsmall cell lung cancer A549 via ROS-mediated NF- $\kappa$ B activation. J Environ Sci 31:146-153. https://doi.org/10.1016/j.jes. 2014.09.041

Zhang H, Zhang S, Wang P, Qin Y, Wang H (2017) Forecasting of particulate matter time series using wavelet analysis and wavelet-ARMA/ARIMA model in Taiyuan, China. J Air Waste Manag Assoc 67(7):776-788. https://doi.org/10.1080/10962247. 2017.1292968

Zhang H, Zhan Y, Li J, Chao CY, Liu Q, Wang C, Biswas P (2021) Using Kriging incorporated with wind direction to investigate ground-level $\mathrm{PM}_{2.5}$ concentration. Sci Total Environ 751:141813. https://doi.org/10.1016/j.scitotenv.2020.141813

Zoran MA, Savastru RS, Savastru DM, Tautan MN (2020) Assessing the relationship between surface levels of $\mathrm{PM}_{2.5}$ and $\mathrm{PM}_{10}$ particulate matter impact on COVID-19 in Milan, Italy. Sci Total Environ 738:139825. https://doi.org/10.1016/j.scitotenv.2020. 139825

Zou L, Ruan F, Huang M, Liang L, Huang H, Hong Z, Wu J (2020) SARS-CoV-2 viral load in upper respiratory specimens of infected patients. N Engl J Med 382(12):1177-1179. https://doi. org/10.1056/NEJMc2001737

Publisher's Note Springer Nature remains neutral with regard to jurisdictional claims in published maps and institutional affiliations. 